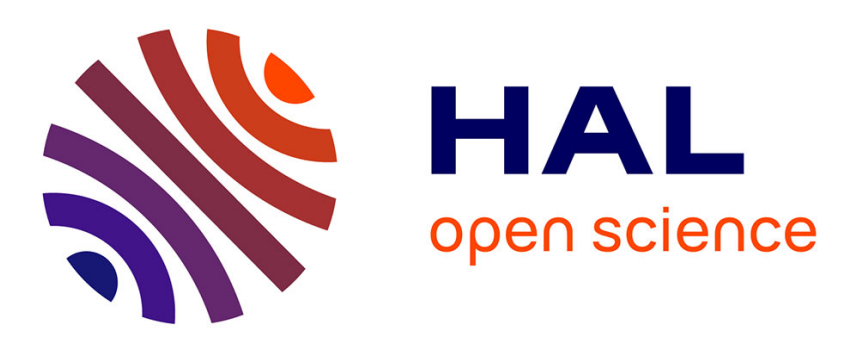

\title{
Effects of population density on the sediment mixing induced by the gallery-diffusor Hediste (Nereis) diversicolor O.F. Müller, 1776
}

Eric Duport, Georges Stora, Pierre Tremblay, Franck Gilbert

\section{To cite this version:}

Eric Duport, Georges Stora, Pierre Tremblay, Franck Gilbert. Effects of population density on the sediment mixing induced by the gallery-diffusor Hediste (Nereis) diversicolor O.F. Müller, 1776. Journal of Experimental Marine Biology and Ecology, 2006, vol. 336, pp. 33-41. 10.1016/j.jembe.2006.04.005 . hal-00780272

\section{HAL Id: hal-00780272 \\ https://hal.science/hal-00780272}

Submitted on 23 Jan 2013

HAL is a multi-disciplinary open access archive for the deposit and dissemination of scientific research documents, whether they are published or not. The documents may come from teaching and research institutions in France or abroad, or from public or private research centers.
L'archive ouverte pluridisciplinaire HAL, est destinée au dépôt et à la diffusion de documents scientifiques de niveau recherche, publiés ou non, émanant des établissements d'enseignement et de recherche français ou étrangers, des laboratoires publics ou privés. 


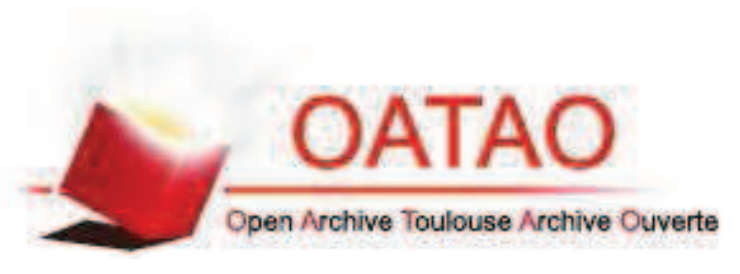

\section{Open Archive Toulouse Archive Ouverte (OATAO)}

OATAO is an open access repository that collects the work of Toulouse researchers and makes it freely available over the web where possible.

This is an author-deposited version published in: http://oatao.univ-toulouse.fr/ Eprints ID: 6096

To link to this article: DOI: $10.1016 /$ j.jembe.2006.04.005

URL: http://dx.doi.org/10.1016/j.jembe.2006.04.005

To cite this version: Duport, Eric and Stora, Georges and Tremblay, Pierre and Gilbert, Franck Effects of population density on the sediment mixing induced by the gallery-diffusor Hediste (Nereis) diversicolor O.F. Müller, 1776. (2006) Journal of Experimental Marine Biology and Ecology, vol. $336\left(n^{\circ} 1\right)$. pp. 33-41. ISSN 0022-0981

Any correspondence concerning this service should be sent to the repository administrator: staff-oatao@,listes.diff.inp-toulouse.fr 


\title{
Effects of population density on the sediment mixing induced by the gallery-diffusor Hediste (Nereis) diversicolor O.F. Müller, 1776
}

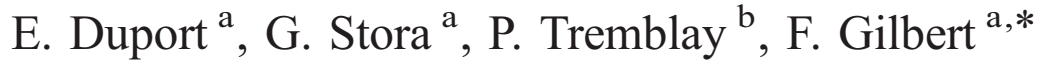 \\ ${ }^{\text {a }}$ Laboratoire de Microbiologie, Géochimie et Ecologie Marines (UMR CNRS 6117), COM, Université de la Méditerranée, \\ Campus de Luminy, Case 901, F-13288 Marseille Cedex 09, France \\ bentre d'Océanologie de Marseille (UMS CNRS 2196) Université de la Méditerranée, Campus de Luminy, \\ Case 901, F-13288 Marseille Cedex 09, France
}

\begin{abstract}
The aim of this work was to quantify the intensity of sediment mixing induced by the gallery-diffusor (functional bioturbation group) Hediste diversicolor as a function of density, using particles tracers (luminophores). In order to assess the impact of density on sediment reworking, a 1-D model was used to obtain sediment reworking coefficients such as Db (biodiffusion-like) and $r$ (biotransport). Densities used in this experiment corresponded to population densities observed in the sampling area (Saint-Antoine Canal, Gulf of Fos, France): 144, 288, 577, 1153 indiv/ $\mathrm{m}^{2}$. At first, results showed that neither luminophore maximum burying depth nor the more marked tracer accumulation areas were influenced by density. Thus density did not seem to have any influence on size of galleries or complexity of structure. Then, density-dependent relations with Db (biodiffusion-like mixing) and $r$ (biotransport) were highlighted with an observed process intensity rate twice as high at highest worm density. On the other hand, $\mathrm{Db}$ and $r$ per capita coefficients were negatively influenced by density. $\mathrm{Db}$ and $r$ per capita at highest density were equal to $\sim 20 \%$ of individual $\mathrm{Db}$ and $r$ obtained at the lowest density. Finally, this study showed the importance of density which appears to be a key parameter in the functioning of the sedimentary ecosystem.
\end{abstract}

Keywords: Bioturbation; Gallery-diffusor; Hediste diversicolor; Luminophores; Population density; Sediment reworking

\section{Introduction}

By modifying the physical, chemical and biological sediment properties, the bioturbation activities of the organisms within soft sediments play a major role in the functioning of marine and limnic ecosystems (Aller, 1982; Posey et al., 1991; Richardson et al., 2002; Kitano et al., 2003; Webb and Eyre, 2004). The active bioturbation processes such as construction of biogenic

\footnotetext{
* Corresponding author. Tel.: +33491829104; fax: +33491829641. E-mail address: gilbert@com.univ-mrs.fr (F. Gilbert).
}

structures, irrigation of burrows, sediment mixing and production of fecal pellets influence the distribution and the fate of organic matter at the water-sediment interface and within the sediment (e.g., Gérino et al., 1995; Lohrer et al., 2004). Recent experiments highlighted the impact of these bioturbation processes on denitrification in sediment (Gilbert et al., 2003), nutrients and oxygen fluxes (Mermillot-Blondin et al., 2005), xenobiotic fate (Zoumis et al., 2001; Fones et al., 2004) and changes in benthic invertebrate (Kearns et al., 1996) and microbe dynamics (Holmer et al., 1997; Goño-Urriza et al., 1999). 
Sediment reworking is one of the most important parameters for the understanding of overall sediment biogeochemistry (Boudreau, 1997). The quantification of this process on the basis of diagenetic models (Berner, 1980; Boudreau, 1997) is very well documented and allows comparison of the intensity of particle transport process induced by different benthic organisms.

The intensity of sediment mixing can vary according to different factors such as species lifespan, population biomass (Matisoff, 1982; Reible et al., 1996; Sandnes et al., 2000), community vertical distribution (Gérino et al., 1999), change in community composition and/or structuration (Duport et al., in press), environmental factors (Gérino et al., 1998; Mortimer et al., 1999; Orvain and Sauriau, 2002) and intraspecific variability within functional groups (Francois et al., 1999). Changes in sediment mixing intensity can be also associated to physical processes such as tidal currents which are able to significantly erode the sediment surface (e.g., Diaz and Cutter, 2001).

According to the literature, five types of functional bioturbation groups exhibiting different modes of sediment mixing may be distinguished: the biodiffusors, upward conveyors, downward conveyors, regenerators and gallery-diffusors (Gardner et al., 1987; Gérino, 1992; Francois et al., 1997, 2001).

Recent studies on organisms belonging to the biodiffusor functional group have shown that changes in population density influence the intensity of community sediment reworking (Sun et al., 1999; Ingalls et al., 2000; Sandnes et al., 2000). Thus, population density appears to be an important factor with regard to the regulation of the intensity of bioturbation processes in lagoonal and coastal ecosystems which present wide variations in population density. In order to assess the importance of this factor in complex ecosystems, it was essential to know whether the density-reworking relationship was the same whatever the functional group considered. The aim of the present work was to quantify the intensity of sediment mixing induced by Hediste diversicolor. This muddy sand sediment species widespread in brackish intertidal areas was chosen as a species representative of the gallery-diffusor functional group (Francois et al., 2002).

\section{Materials and methods}

\subsection{Sampling and experimental setup}

In July 2002, sediments and forty five $H$. diversicolor (individual wet weight: $0.33 \pm 0.03 \mathrm{~g}$; mean $\pm \mathrm{SD}$ ) were randomly collected at $\sim 0.5 \mathrm{~m}$ water depth in the SaintAntoine Canal. This canal links the Rhone River is opened to the Carteau Cove (Gulf of Fos) (Fig. 1) near Marseilles, France. In the laboratory, collected sediments were sieved through a $250 \mu \mathrm{m}$ mesh to remove

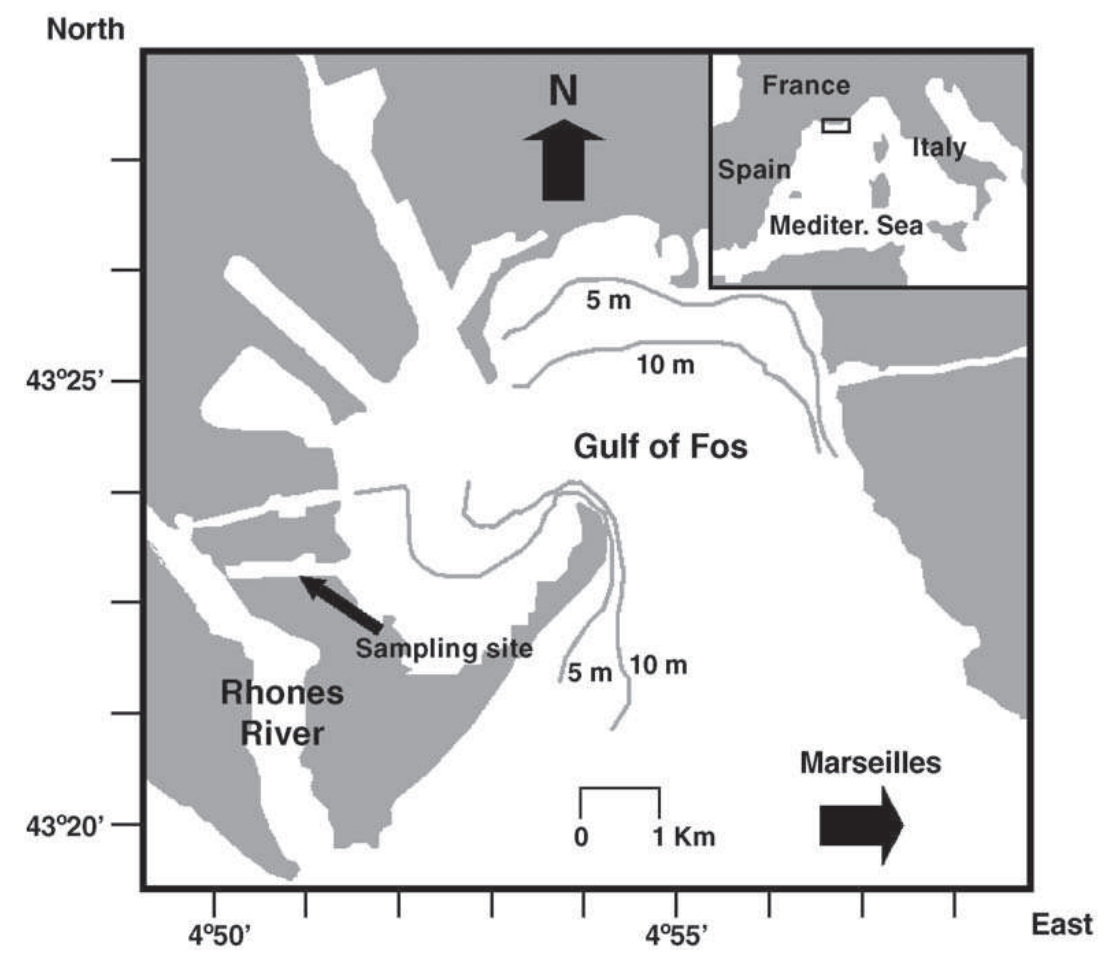

Fig. 1. Map of sampling site in the Saint-Antoine Canal (Gulf of Fos, France). 
macrofauna and large debris, then thoroughly homogenized by gloved hands. Fifteen PVC cores (I.D.: $9.4 \mathrm{~cm}$ diameter; height: $30 \mathrm{~cm}$ ) were then filled to a depth of $15 \mathrm{~cm}$ with macrofauna-free sediment and placed during 7 days in one aquarium thermostated at $26{ }^{\circ} \mathrm{C}$ (in situ temperature) under a water flow system. At the same time, the polychaetes were separated from sediment by gentle elution in seawater. The worms were acclimatized to experimental conditions for $7 \mathrm{~d}$ in a recirculating seawater aquarium filled with natural sediment. Then, 1 , 2,4 or 8 individuals were added to 12 cores (triplicates), respectively corresponding to densities of $144,288,577$, 1153 indiv $/ \mathrm{m}^{2}$, which are densities frequently observed in the sampling area. The three remaining cores without any macrofauna were used as controls.

\subsection{Sediment reworking}

We used the luminophore technique (Gérino et al., 1998) in order to quantify the sediment reworking activity. One day after the introduction of animals into the sediment, the overlying water was removed and fluorescent luminophores ( $2 \mathrm{~g} ; 125-250 \mu \mathrm{m}$ diameters) were deposited at the sediment surface. Then, the water flow system was re-activated. After 9 days of incubation, the sediment cores were sectioned $(0.5 \mathrm{~cm}$ thick layers). Samples were then freeze-dried, gently crushed to powder and homogenized. In order to quantify tracers, sediment subsample $(0.15 \mathrm{~g})$ was homogeneously spread in a dish $(4 \times 4 \mathrm{~cm})$ which was placed inside a dark box $(50 \times 40 \times 40 \mathrm{~cm})$ and illuminated with a UV light source (wide and constant range of wavelength). Sediment subsamples were always placed at the same distance from the light source. One photograph was taken for each sediment subsample, using a digital camera (Olympus C-2500L) fixed at the top of the box. Finally, the surface (pixels number) occupied by tracers was quantified with an image analysis software (image $\mathrm{J}$; http://rsb.info.nih.gov/ij/).

\subsection{Sediment reworking data modeling}

The reaction-diffusion type model used in this paper to describe luminophore redistribution following macrofaunal reworking is based on the general diagenetic equation (Berner, 1980):

$\frac{\partial Q}{\partial t}=\frac{\partial}{\partial z}\left(\mathrm{Db} \frac{\partial Q}{\partial z}\right)+R(Q)$

where $Q$ is the quantity of the tracer, $t$ the time, $z$ the depth, $\mathrm{Db}$ the apparent biodiffusion-like coefficient, and
$R(Q)$ the non-continuous displacement of tracer. The term $R(Q)$ is defined as follows:

$$
R(Q(z, t))=\left\{\begin{array}{l}
\frac{r}{z_{2}-z_{1}} \int_{0}^{x_{1}} Q(x, t) d x \text { if } z \in\left[z_{1} ; z_{2}\right] \\
-r Q(z, t) \text { if } z \in\left[0 ; z_{1}\right] \\
0 \text { if } z>z_{2}
\end{array}\right.
$$

where $z_{1}$ and $z_{2}$ define the upper and lower limits of the tracer redistribution, $x$ and $z$ are depth variables and $r$ is the biotransport coefficient that is the percentage of tracer that left the $\left[0, x_{1}\right]$ deposit and was redistributed in the $\left[z_{1}, z_{2}\right]$ layer. The redistribution of tracer between $z_{1}$ and $z_{2}$ and the disappearance of tracer from the $0-z_{1}$ layer are respectively described by Eq. (2a) and (2b). Eq. (2c) indicates that no tracer movement occurs below $z_{2}$.

This displacement term was originally exemplified in a model describing gallery-diffusion of macrofaunal reworking (Francois et al., 2002). This biological reworking process describes the diffusive-like mixing of particles in the region of intense burrowing activity and the rapid transport of organic and inorganic material from the upper sediment layers to the lower regions of reworking (i.e. 'biotransport').

According to the experimental conditions, the following initial conditions were used:

$Q(z, 0)=\left\{\begin{array}{l}Q_{0} \text { if } z \in\left[x_{1} ; x_{2}\right] \\ 0 \text { else }\end{array}\right.$

where $\left[x_{1} ; x_{2}\right]$ is the tracer deposit layer.

Finally, a zero-flux Neuman boundary condition was considered:

$\frac{\partial Q}{\partial z}(0, t)=\lim _{z \rightarrow+\infty} \frac{\partial Q}{\partial z}(z, t)=0$

The application of this bioturbation model to tracer redistributions allowed the quantification of two particle mixing coefficients: an apparent biodiffusion-like coefficient $\mathrm{Db}$ and a biotransport coefficient $r$. The biodiffusion-like coefficient $\mathrm{Db}$ takes into account the diffusion-like transport due to the activity of the organisms. We assume that the actual concentration dependent diffusion of tracers is negligible. The biotransport coefficient $(r)$ represents a non-local mixing pattern associated with a biologically induced transfer of particles from one place to another in a discontinuous pattern (i.e. a non-continuous transport; Boudreau, 1986; Meysman et al., 2003). 


\subsection{Data analysis}

Luminophore maximum burying depth, biodiffusionlike $(\mathrm{Db})$ and biotransport coefficient $(r)$ data as a function of worm density were analyzed by linear correlation analysis to determine possible densitydependent relationships. Estimated biodiffusion-like $(\mathrm{Db})$ and biotransport $(r)$ coefficient rates per worm as a function of $H$. diversicolor density were studied by both linear correlation analysis and 1-way ANOVA to determine possible density-dependent relationships. Homogeneity of variances was evaluated using Bartle-

\section{Luminophores (\%)}

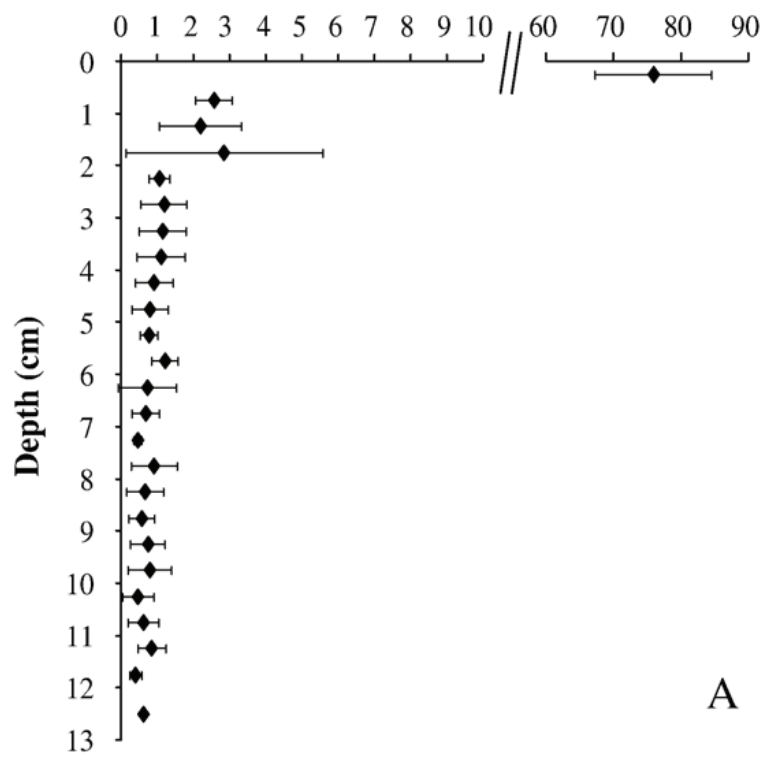

Luminophores (\%)

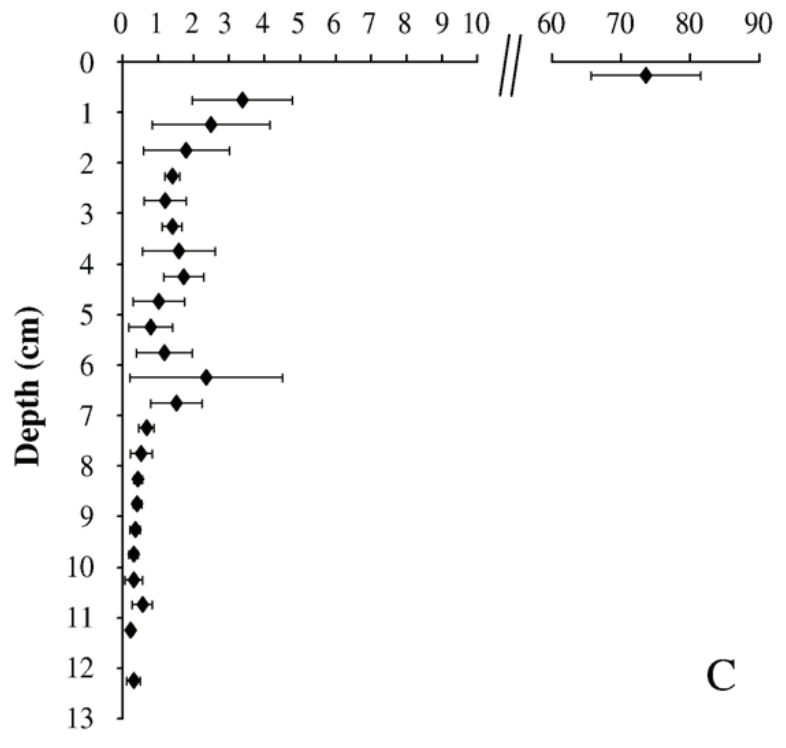

$\mathrm{tt}$ 's test. When variances were found to be heterogeneous, data were square-transformed according to Underwood (1997) to obtain homoscedastic data. Differences were accepted as significant at $p<0.05$. Pairways testing of means was done with StudentNewman-Keuls multiple comparison test (SNK).

\section{Results}

In the controls, $98.4 \pm 0.3 \%$ of tracers were found in the deposit layer. Few tracers were detected in the $0.5-$ $1 \mathrm{~cm}$ layer (data not shown). In the inhabited sediment

\section{Luminophores (\%)}

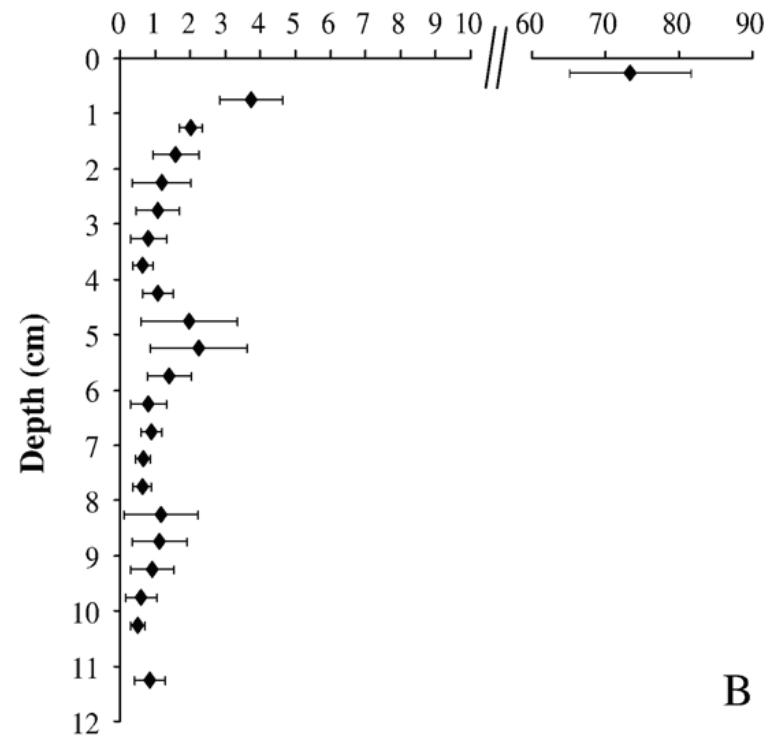

Luminophores (\%)

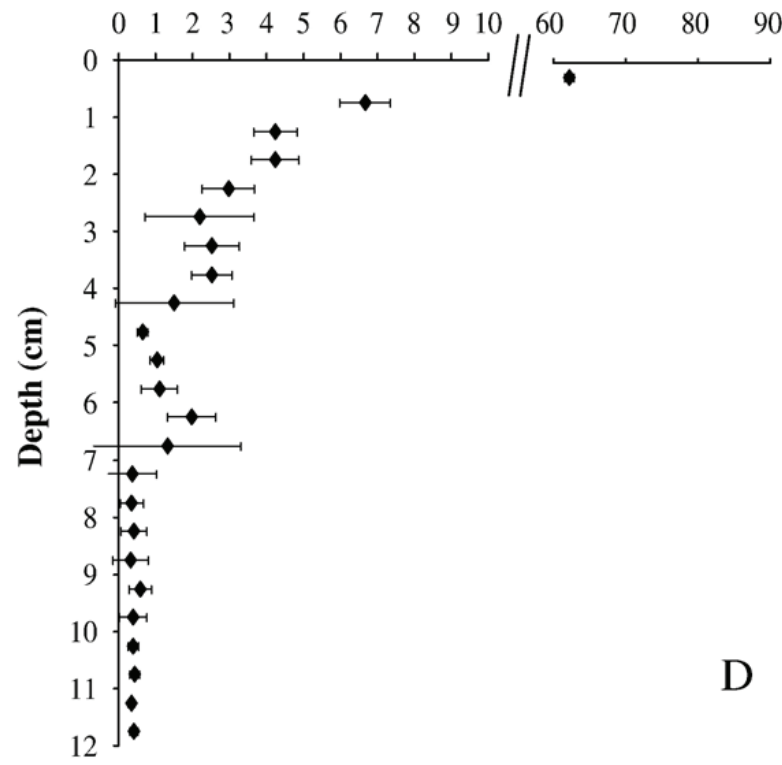

Fig. 2. Luminophore profiles (mean $\pm \mathrm{SD} ; n=3$ ) in the inhabited sediments, after 9 days. A: 144 indiv $/ \mathrm{m}^{2}, \mathrm{~B}: 288$ indiv $/ \mathrm{m}^{2}, \mathrm{C}: 577 \mathrm{indiv} / \mathrm{m}^{2}$, and $\mathrm{D}$ : 1153 indiv $/ \mathrm{m}^{2}$. 


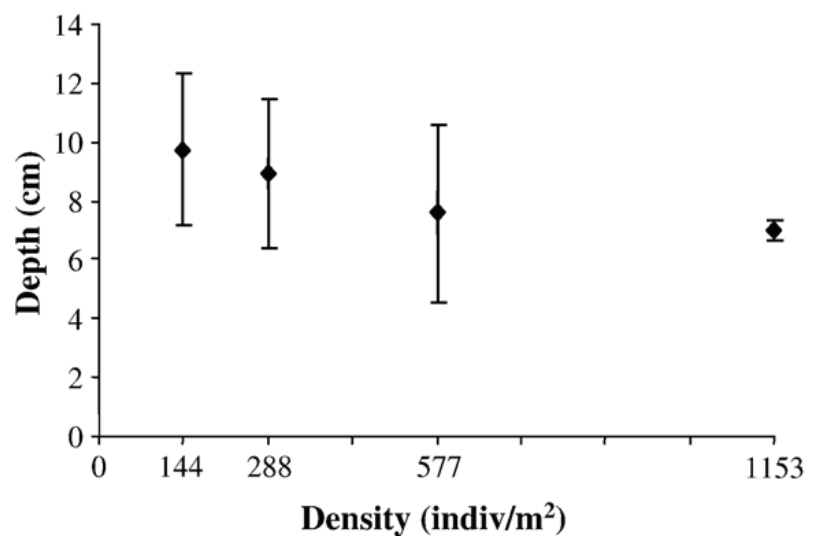

Fig. 3. Luminophore maximum burying depth as a function of Hediste diversicolor density. Values are presented as mean $\pm \mathrm{SD}$ for triplicates.

cores, luminophore profiles (Fig. 2) showed a rapid exponential decrease of the tracers from the surface to $\sim 1 \mathrm{~cm}$ (for the two lowest densities) or $\sim 2 \mathrm{~cm}$ (for the two highest densities) depth and then an accumulation of particles deeper down. Amount of tracers found in the deposit layer $(0-0.5 \mathrm{~cm})$ ranged from $62.2 \pm 0.7 \%$ (highest density) to $75.9 \pm 8.6 \%$ (lowest density). If no difference between the quantity of tracers remaining in the deposit layer was noted for the two intermediate densities: $73.4 \pm 8.2 \%\left(288 \mathrm{indiv} / \mathrm{m}^{2}\right)$ and $73.6 \pm 7.9 \%$
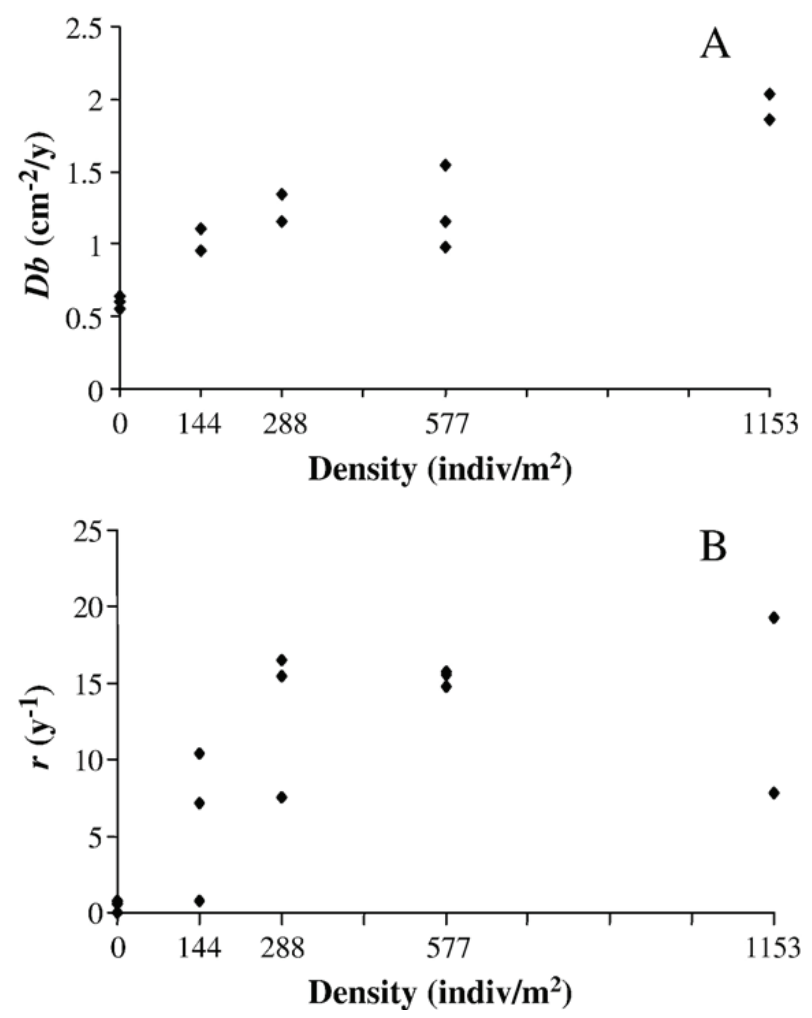

Fig. 4. Apparent biodiffusion-like coefficient $(\mathrm{Db})$ and biotransport coefficient $(r)$ as a function of Hediste diversicolor density. Values are presented as mean \pm SD for triplicates.
(577 indiv $/ \mathrm{m}^{2}$ ), an increase of burying quantity of tracers with density was observed overall.

The luminophore maximum burying depth, defined here as the depth integrating $99 \%$ of buried tracers, varied from $7.0 \pm 0.3$ to $10.0 \pm 2.6 \mathrm{~cm}$ (mean $\pm \mathrm{SD}, n=3$; Fig. 3), for $1153 \mathrm{indiv} / \mathrm{m}^{2}$ and $144 \mathrm{indiv} / \mathrm{m}^{2}$, respectively. No significant difference, however, was found between the four studied $H$. diversicolor densities $(p>0.05, F=1.678)$.

Sediment reworking coefficients: biodiffusion-like $(D b)$ and biotransport $(r)$ calculated from data profiles (Fig. 4) showed an increase of the biodiffusion-like coefficient as a function of organism density. Linear Correlation analysis highlighted a significantly link between $\mathrm{Db}$, ranging from $1.1 \pm 0.1$ (lowest density) to $2.0 \pm 0.1 \mathrm{~cm}^{-2} / \mathrm{y}$ (highest density), and density values $\left(p<0.001, F=41.996, r^{2}=0.78\right)$.

The biotransport coefficient also showed an increase with density. Linear correlation analysis of $r$, ranging from $11.4 \pm 4.7$ (lowest density) to $19.5 \pm 0.4 \mathrm{y}^{-1}$ (highest density), as a function of density indicated a significant link between them $\left(p<0.01, F=14.006, r^{2}=0.54\right)$.

Taking into account sediment reworking achieved per worm as a function of density, results showed a decrease of $\mathrm{Db}$ and $r$ per individual with increasing density (Fig. 5). Db per worm ranged for $1.1 \pm 0.1$
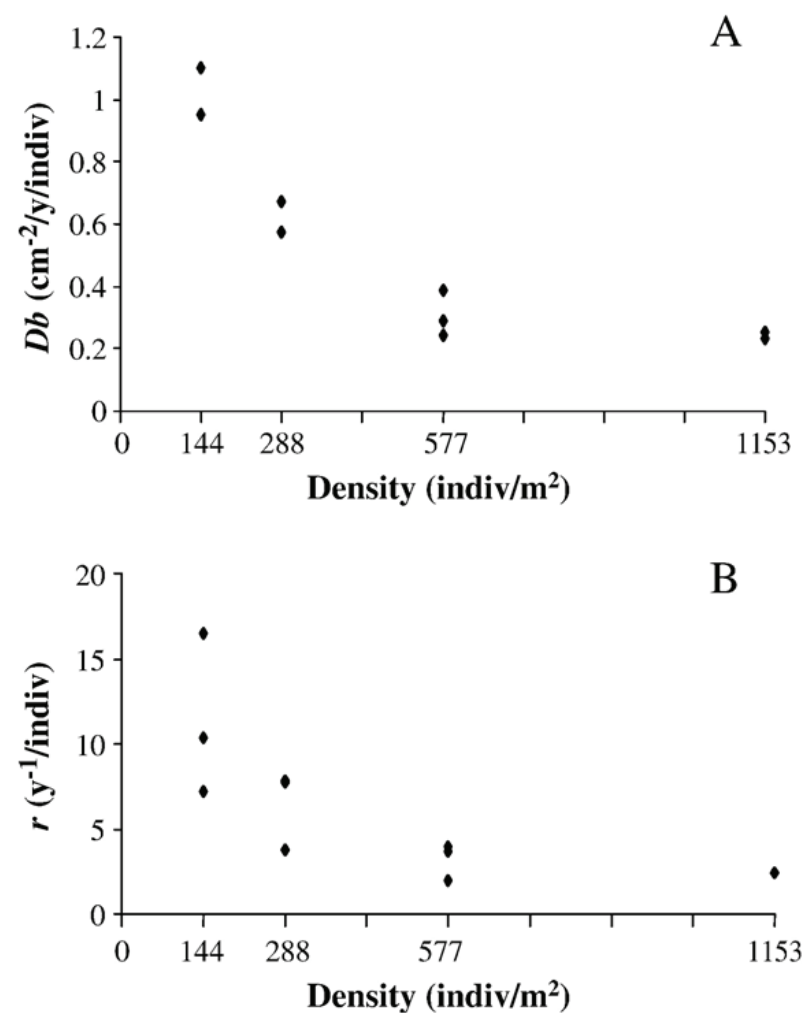

Fig. 5. Apparent biodiffusion-like coefficient $(\mathrm{Db})$ and biotransport coefficient $(r)$ per worm as a function of Hediste diversicolor density. Values are presented as mean $\pm \mathrm{SD}$ for triplicates. 
Table 1

Pairways testing of $\mathrm{Db}$ and $r$ mean coefficient rates per worm with Student-Newman-Keuls multiple comparison test (SNK)

\begin{tabular}{lll}
\hline \multirow{2}{*}{$\begin{array}{l}\text { Densities compared } \\
\left.\text { (indiv/ } \mathrm{m}^{2}\right)\end{array}$} & \multicolumn{2}{c}{$p$} \\
\cline { 2 - 3 } & $\mathrm{Db}\left(\mathrm{cm}^{2} / \mathrm{y} /\right.$ indiv $)$ & $r\left(\mathrm{y}^{-1} /\right.$ indiv $)$ \\
\hline 144 vs. 1153 & $<0.001$ & 0.017 \\
144 vs. 577 & $<0.001$ & 0.019 \\
144 vs. 288 & $<0.001$ & 0.093 \\
288 vs. 1153 & $<0.001$ & 0.133 \\
288 vs. 577 & $<0.001$ & 0.128 \\
577 vs. 1153 & 0.314 & 0.639 \\
\hline
\end{tabular}

(lowest density) to $0.2 \pm 0.0 \mathrm{~cm}^{-2} / \mathrm{y}$ (highest density) and $r$ per worm ranged for $11.4 \pm 4.7$ (lowest density) to $2.4 \pm 0.1 \mathrm{y}^{-1}$ (highest density). Linear correlation analysis showed a density-relationship between individual $\mathrm{Db}$ intensity and the density $\left(p<0.01, F=18.977, r^{2}=0.68\right)$ and revealed a significant link between individual $r$ and density values $\left(p<0.05, F=8.14, r^{2}=0.48\right)$. Analysis of variance showed a significant difference between sediment reworking coefficients per worm, $\mathrm{Db}(p<0.001$, $F=81.23)$ and $r(p=0.015, F=7.29)$, for the densities used. Moreover, normalized sediment reworking coefficients per worm indicated minimum values but insignificantly different for the two highest densities (SNK test, Table 1).

\section{Discussion and conclusions}

\subsection{H. diversicolor sediment reworking}

Luminophore distribution profiles obtained confirmed that the studied organism belongs to the gallery-diffusor functional group (Francois, 1999). Main sediment reworking parameters appeared to be in complete agreement with the study by Francois et al. (2001) that described, for $H$. diversicolor, sediment reworking regrouping two processes: a biodiffusion-like $(\mathrm{Db})$ mixing occurring in the surface layer where the gallery network is dense, and an accumulation of particles in the gallery bottom resulting from non-local transport $(r)$. This mode of mixing is explained by organism movements in the complex U or Y shape sedimentary biogenic structures (Gérino, 1992) and their nutrition mode switching between suspension and deposit feeder (Riisgard, 1991) which generate a transport of particles from the surface layer down to the sediment (Gérino, 1992). Furthermore, particles drop into the gallery and are transferred down to the bottom by bioirrigation processes, with a flow of 1$3 \mathrm{ml} / \mathrm{min}$ (Foster-Smith, 1978; Kristensen, 1981; Gérino, 1989). Particles can also be fixed at any level in biogenic structure walls due to the mucus secreted by $H$. diversicolor (Gérino and Stora, 1991; Olivier, 1994; Peterson et al., 1998). Our results showed tracer accumulation areas at different depths in the sediment which corresponded to gallery bottom or horizontal gallery sections. The more marked accumulation areas were similar for the three highest densities (from 5 to $7 \mathrm{~cm}$ depth). Moreover, no significant difference in the average maximum depth of burying tracers was found. Thus, density did not seem to affect the size and complexity of gallery structures.

\subsection{Density effect on sediment reworking}

Statistical results highlighted a significant effect of density on biodiffusive-like and biotransport processes. Non-linear density-dependent relationships in sediment reworking ( $\mathrm{Db}$ and $r$ ) could be explained by trophic and locomotive behavior changes of the polychaete.

A previous study of $H$. diversicolor trophic behavior showed that the polychaete prospecting area was near the gallery aperture (Esnault et al., 1990). During food foraging, polychaetes extend $33-50 \%$ of their body out of the burrow (Copland and Brown, 1934; Roe, 1975), but usually ingest food in burrows (Goerke, 1971a,b). This behavior of $H$. diversicolor induces a displacement of surface particles down to the gallery bottom. If worm density increases, the whole prospecting area then increases. Thus, a more significant quantity of tracers is buried at high density than at low density. We can realistically consider that there is a linear relationship between density and reworking when no competition occurs. On the other hand, a study of $N$. virens (Miron et al., 1991), which has similar behavior patterns to $H$. diversicolor (Lambert and Retière, 1987; Charrois, 1990; Gilbert et al., 2001), showed individual extension of the prospecting trophic area near the gallery aperture when density reached highest density. This enhancement of the prospecting area for food seeking was explained by trophic competition.

To maintain good irrigation of the burrows (Miron et al., 1992), notably at high density, shape and size of galleries are modified (Miron et al., 1991) by worms during the maintenance phase. Increases in worm density enhance the instability of the sediment (Luckenbach, 1986; De Deckere et al., 2001). So the duration of the maintenance phase is longer at high density than at low density (Miron et al., 1992) to maintain good irrigation inside galleries. Moreover, to optimize oxygenation of the burrow, Nereidae ventilation activity was shown to increase with density and so contribute to enhancement of downward particle transport from the gallery bottom (Ouellette et al., 2004). During the 
maintenance phase, surface particles mixed with mucus are moved to the burrow lining. Rapid and direct transfer of surface particles towards the bottom of the burrow takes place when the worm moves back to its burrow (Charrois, 1990; Ouellette et al., 2004). Due to changes in worm behavior induced by density enhancement, the quantity of buried particles in the galleries increases. Thus, during food seeking, maintenance and ventilation activities it appears that the polychaetes generate more intensive sediment reworking at high density than at low density.

This study of $H$. diversicolor shows a densityrelationship with sediment mixing. Previous studies dealing with Echinocardium cordatum (Sandnes et al., 2000) and Yoldia limatula (Sun et al., 1999; Ingalls et al., 2000), two species belonging to the biodiffusor functional group, also showed density-dependent relationships with sediment mixing. Thus, it appears that both functional groups show a similar relationship between density and sediment reworking.

If the overall community sediment reworking activity was stimulated by the density increase, however, individual sediment reworking activity (Db and $r$ per worm) decreased with density enhancement (Fig. 5).

This reduced individual activity could be explained by the slowdown of the growth rate of $H$. diversicolor at high density (Esnault et al., 1990; Scaps et al., 1993). But the duration of our experiment did not seem to be long enough to generate a growth slowdown. It would be reasonable to suppose, however, that a trophic adaptation due to the increase in density might be the main explanation for the decrease in individual organism activity. Miron et al. (1991) showed a $\sim 20 \%$ reduction in the duration of food seeking by an organism ( $N$. virens) with density enhancement. Furthermore, at high density, the nearness of organisms induces competition for trophic resources and territory (interaction between galleries) which become limiting parameters (Bridges et al., 1996). To defend their own territory, the combative behavior of Nereis is enhanced at high density (Miron et al., 1992). This would reduce their food seeking, maintenance and ventilation activities and result in a decrease of omnidirectional mixing (Miron et al., 1991). This could explain why individual sediment mixing induced by $H$. diversicolor decreases with density. Levinton $(1979,1985)$ previously showed the influence of density on feeding rate and crawling behavior of Hydrobia ventrosa and $H$. totteni which decreased above $1 \mathrm{snail} / \mathrm{cm}^{2}$. Moreover, E. cordatum and $Y$. limatula also exhibited a decrease in their individual mixing activity with density (Sun et al., 1999; Ingalls et al., 2000; Sandnes et al., 2000).

Our results show that both $\mathrm{Db}$ and $r$ per worm reached minimum values at highest densities (Table 2). This could indicate the lowest individual activity level allowing $H$. diversicolor, under our experimental conditions, to maintain good sedimentary ecosystem functioning.

As a previous study has shown (Heilskov and Holmer, 2001), organic matter mineralization is stimulated by the presence of burrowing organisms such as $H$. diversicolor which improved sediment ventilation and the $\mathrm{O}_{2}$ requirement. Thus, changes in the intensity of bioturbation processes induced by population density could have an influence on the fate of organic matter. In this way, the model proposed by Kristensen and Holmer (2001) suggested that organic matter mineralization was more strongly stimulated by irrigation than sedimentary reworking above a certain population density. Nevertheless, both sediment reworking activity and irrigation increase with density were necessary for enhancement of total sediment carbon oxidation due to increased microbial degradation (Kristensen and Holmer, 2001).

To conclude, our results highlight, for the gallerydiffusor $H$. diversicolor, both an increase in community sediment reworking intensity and a decrease in individual sediment reworking intensity with density. This could be explained essentially by bioturbation and trophic behavior changes.

Density-sediment reworking relationships seem to be similar whatever the mixing mode, for the two functional groups considered (biodiffusor, gallerydiffusor). Nevertheless, this must be confirmed for the other groups. Also it would be interesting to study the density-sediment reworking relationships with communities where interactions between species/functional groups can occur. Thus, as a result of its implication in particle transport and organic matter transformation processes, density appears to be a key parameter in the functioning of sedimentary ecosystems.

Table 2

Densities regrouping as function of differences in the $\mathrm{Db}$ and $r$ mean coefficient rates per worm obtained with the Student-Newman-Keuls multiple comparison test (SNK)

\begin{tabular}{llllllllll}
\hline Densities (indiv $\left./ \mathrm{m}^{2}\right)$ & \multicolumn{2}{l}{$\mathrm{Db}\left(\mathrm{cm}^{2} / \mathrm{y} /\right.$ indiv $)$} & & & \multicolumn{2}{l}{$\left(\mathrm{y}^{-1} /\right.$ indiv $)$} \\
\cline { 2 - 3 } & Mean & Groups & & & Mean & Groups \\
\hline 144 & 1.05 & A & & & 11.37 & A & \\
288 & 0.64 & & B & & 6.43 & A & B \\
577 & 0.31 & & & C & 3.20 & & B \\
1153 & 0.24 & & & C & 2.44 & & B \\
\hline
\end{tabular}




\section{Acknowledgements}

This paper is a part of Eric Duport PhD thesis work. We thank Michael Paul for reading the manuscript and anonymous reviewers who significantly helped to improve the ms. This work was supported by the EU commission (STREP COBO; contract number GOCECT-2003-505564). Nereis Park contribution number 16. [SS]

\section{References}

Aller, R.C., 1982. The effects of macrobenthos on chemical properties of marine sediment and overlying water. In: Mc Call, P.L., Tevesz, M.J.S. (Eds.), Animal-Sediments Relations. Plenum press, New York, pp. 53-102.

Berner, R.A., 1980. Early Diagenesis: A Theoretical Approach. Princeton University Press, Princeton, New-Jersey.

Boudreau, B.P., 1986. Mathematics of tracer mixing in sediments: II. Nonlocal mixing and biological conveyor-belt phenomena. Am. J. Sci. 286, 199-238.

Boudreau, B.P., 1997. Diagenetic Models and Their Implementation: Modelling Transport and Reactions in Aquatic Sediments. Springer-Verlag, Berlin.

Bridges, T.S., Farrar, J.D., Gamble, E.V., Dillon, T.M., 1996. Intraspecific density effects in Nereis (Neanthes) arenaceodentata Moore (Polychaeta: Nereidae). J. Exp. Mar. Biol. Ecol. 195, 221-239.

Charrois, H., 1990. La bioturbation estivale de Nereis (Neanthes) virens (Sars) (polychètes) adultes: perturbations sédimentaires. Mémoire de maîtrise. Université du Québec à Rimouski, Rimouski.

Copland, M., Brown, A., 1934. Modification of behaviour in Nereis virens. Biol. Bull. (Woods hole, Mass) 67, 356-364.

De Deckere, E.M.G.T., Tolhurst, T.J., De Brouwer, J.F.C., 2001. Destabilization of cohesive intertidal sediments by infauna. Estuar., Coast. Shelf Sci. 145, 65-77.

Diaz, R.J., Cutter Jr., G.R., 2001. In situ measurements of organismsediment interaction: rates of burrow formation, abandonment and sediment oxidation, reduction. In: Aller, J.Y., Woodin, S.A., Aller, R.C. (Eds.), Organism-Sediment Interactions. The Belle W. Barush Library in Marine Science, vol. 21. University of South Carolina, Columbia, pp. 19-32.

Duport, E., Gilbert, F., Poggiale, J.C., Dedieu, K., Rabouille, C., Stora, G., in press. Benthic macrofauna and sediment reworking quantification in contrasted environment in the Thau Lagoon. Estuarine, Coast. Shelf Sci.

Esnault, G., Retière, C., Lambert, R., 1990. Food resource partitioning in a population of Nereis diversicolor under experimental conditions. In: Barnes, M., Gibson, R.N. (Eds.), Trophic Relationships in the Marine Environment, Proc. 24th Europ. Mar. Biol. Symp. Arberdeen University Press, pp. 453-467.

Fones, G.R., Davison, W., Hamilton-Taylor, J., 2004. The fine-scale remobilization of metals in the surface sediment of the North-East Atlantic. Cont. Shelf Res. 24, 1485-1504.

Foster-Smith, R., 1978. An analysis of water flow in tube living animals. J. Exp. Mar. Biol. Ecol. 34, 73-95.

Francois, F., 1999. Mise au point d'un nouveau modèle de bioturbation pour une approche fonctionnelle du remaniement sédimentaire lié à l'activité des communautés macrobenthiques. Thèse de Docteur es Sciences, Université Aix-Marseille II.
Francois, F., Poggiale, J.C., Durbec, J.P., Stora, G., 1997. A new model approach for the modelling of sediment reworking induced by a macrobenthic community. Acta Biotheor. 45, 295-319.

Francois, F., Dalegre, K., Gilbert, F., Stora, G., 1999. Variabilité spécifique à l'intérieur des groupes fonctionnels. Etude du remaniement sédimentaire de deux bivalves Veneridae, Ruditapes decussatus et Venerupis aurea. C.R. Acad. Sci., Paris, Sci. Vie 322, 339-345.

Francois, F., Poggiale, J.C., Durbec, J.P., Stora, G., 2001. A new model of bioturbation for a functional approach to sediment reworking resulting from macrobenthic communities. In: Aller, J.Y., Woodin, S.A., Aller, R.C. (Eds.), Organism-Sediment Interactions. The Belle W. Barush Library in Marine Science, vol. 21. University of South Carolina, Columbia, pp. 73-86.

Francois, F., Gérino, M., Stora, G., Durbec, J.P., Poggiale, J.C., 2002. Functional approach to sediment reworking by gallery-forming macrobenthic organisms: modelling and application with the polychaete Nereis diversicolor. Mar. Ecol. Prog. Ser. 229, 127-136.

Gardner, L.R., Sharma, P., Moore, W.S., 1987. A regeneration model for the effect of bioturbation by fiddler crabs on ${ }^{210} \mathrm{~Pb}$ profiles in salt marsh sediments. J. Environ. Radioact. 5, 25-36.

Gérino, M., 1989. Approche des processus de Bioturbation: une technique de mesure de la bioturbation. J. Rech. Oceanogr. 1-2, 24-27.

Gérino, M., 1992. Etude expérimentale de la bioturbation en milieu littoral et profond. Quantification des structures de bioturbation et modélisation du remaniement biologique du sédiment. Thèse de Docteur es science, université Aix-Marseille II.

Gérino, M., Stora, G., 1991. Analyse quantitative in vitro de la bioturbation induite par le polychète Nereis diversicolor. C. R. Acad. Sci., Paris, Sci. Vie 313, 489-494.

Gérino, M., Stora, G., Poydenot, F., Bourcier, M., 1995. Benthic fauna and bioturbation on the Mediterranean continental slope: Toulon Canyon. Cont. Shelf Res. 15 (11-12), 1483-1496.

Gérino, M., Aller, R.C., Lee, C., Cochran, J.K., Aller, J.Y., Green, M.A., Hirschberg, D., 1998. Comparison of different tracers and methods used to quantify bioturbation during a spring bloom: ${ }^{234} \mathrm{Th}$, luminophores and chlorophyll $a$. Estuar., Coast. Shelf Sci. 46, 531-547.

Gérino, M., Stora, G., Weber, O., 1999. Evidence of bioturbation in the Cap-Ferret Canyon in the deep northeastern Atlantic. Deep-Sea Res. II 46, 2289-2307.

Gilbert, F., Desrosiers, G., Hulth, S., Stora, G., 2001. Comparison between the Nereis diversicolor and Nereis virens marine worms in the transformation of ingested hydrocarbons. J. Mar. Biol. Assoc. U.K. 81, 885-886.

Gilbert, F., Aller, R.C., Hulth, S., 2003. The influence of macrofaunal burrow spacing and diffusive scaling on sedimentary nitrification and denitrification: an experimental simulation and model approach. J. Mar. Res. 61, 101-125.

Goerke, H., 1971a. Die Ernahrungsweise des Nereis-Arten (Polyhaeta, Nereidae) der deutschen Küsten. Voroeff. Inst. Meeresforsch. Bremerhav. 13, 1-51.

Goerke, H., 1971b. Nahrungsaufnahme, Nahrungsaufnutzung und Watchstum von Nereis virens (Polyhaeta, Nereidae). Voroeff. Inst. Meeresforsch. Bremerhav. 13, 51-78.

Goño-Urriza, M., De Montaudouin, X., Guyoneaud, R., Bachelet, G., De Wit, R., 1999. Effect of macrofaunal bioturbation on bacterial distribution in marine sandy sediments, with special reference to sulphur-oxidising bacteria. J. Sea Res. 41, 269-279.

Heilskov, A.C., Holmer, M., 2001. Effects of benthic fauna on organic matter mineralization in fish-farm sediments: importance of size and abundance. ICES J. Mar. Sci. 58, 427-434 
Holmer, M., Forbes, V.E., Forbes, T.L., 1997. Impact of the polychaete Capitella sp. I on microbial activity in an organic-rich marine sediment contaminated with polycyclic hydrocarbon Fluoranthene. Mar. Biol. 128, 679-688.

Ingalls, A.E., Aller, R.C., Lee, C., Sun, M.Y., 2000. The influence of deposit-feeding on chlorophyll-a degradation in coastal marine sediments. J. Mar. Res. 58, 631-651.

Kearns, C.M., Hairston, N.G., Kelster, D.H., 1996. Particle transport by benthic invertebrates: its role in egg bank dynamics. Hydrobiologia 332, 63-70.

Kitano, M., Kurata, K., KozukI, Y., MurakamI, H., Yamasaki, T., Yoshida, H., Sasayama, H., 2003. Effects of deposit feeder Stichopus japonicus on algal bloom and organic matter contents of bottom sediments of the enclosed sea. Mar. Pollut. Bull. 47, 118-125.

Kristensen, E., 1981. Direct measurement of ventilation and oxygen uptake in 3 species of tubiculous Polychaete (Nereis). J. Comp. Physiol. 145, 45-50.

Kristensen, E., Holmer, M., 2001. Decomposition of plant materials in marine sediment exposed to different electron acceptors $\left(\mathrm{O}_{2}, \mathrm{NO}_{3}^{-}\right.$, and $\mathrm{SO}_{4}^{2-}$ ), with emphasis on substrate origin, degradation kinetics, and the role of bioturbation. Geochim. Cosmochim. Acta 65 (3), 419-433.

Lambert, R., Retière, C., 1987. Etude de la territorialité chez Nereis diversicolor (Annélide polychaete). C. R. Hebd. Séances Acad. Sci., Paris 305, 643-647.

Levinton, J.S., 1979. The effect of density upon deposit-feeding populations: movement, feeding, and floating of Hydrobia ventrosa Montagu (Gasteropoda: Prosobranchia). Oecologia (Berlin) 43, 27-39.

Levinton, J.S., 1985. Complex interactions of a deposit feeder with its resources, roles of density, a competitor, and detrital addition in the growth and survival of the mudsnail Hydrobia totteni. Mar. Ecol. Prog. Ser. 22, 31-40.

Lohrer, A.M., Thrush, S.F., Gibbs, M.M., 2004. Bioturbators enhance ecosystem function through complex biogeochemical interactions. Nature 431, 1092-1095.

Luckenbach, M.W., 1986. Sediment stability around animal tubes: the roles of hydrodynamic processes and biotic activity. Limnol. Oceanogr. 31, 779-787.

Matisoff, G., 1982. Mathematical models of bioturbation. In: McCall, P.L., Tevesz, M.J.S. (Eds.), Animal Sediment Relations. Plenum Press, New York, pp. 289-330.

Mermillot-Blondin, F., Nogaro, G., Datry, T., Malard, F., Gibert, J., 2005. Do tubificid worms influence the fate of organic matter and pollutants in stormwater sediments? Environ. Pollut. 134, 57-69.

Meysman, F.J.R, Boudreau, B.P., Middleburg, J.J., 2003. Relations between local, nonlocal, discrete and continuous models of bioturbation. J. Mar. Res. 61, 391-410.

Miron, G., Desrosiers, G., Retière, C., Lambert, R., 1991. Dispersion and prospecting behaviour of the polychaete Nereis virens (Sars) as a function of density. J. Exp. Mar. Biol. Ecol. 145, 65-77.

Miron, G., Desrosiers, G., Retière, C., Masson, S., 1992. Variation in time budget of the Polychaete Nereis virens as a function of density and acclimatation to a new borrow. Mar. Biol. 114, 41-48.

Mortimer, R.J.G., Davey, J.T., Krom, M.D., Watson, P.G., Frickers, P.E., Clifton, R.J., 1999. The effect of macraufauna on porewater profiles and fluxes in the intertidal zone of the Humber estuary. Estuar., Coast. Shelf Sci. 48, 683-699.

Olivier, M., 1994. Ethologie comparée de l'alimentation de deux espèces vicariantes de la communauté à Macoma balthica: Nereis diversicolor (Baie du Mont saint Michel, France) et de Nereis virens (Estuaire maritime du St Laurent, Canada). Thèse doctorat es science, université du Québec à Rimouski.

Orvain, F., Sauriau, P.G., 2002. Environmental and behavioural factors affecting activity in the intertidal gastropod Hydrobia ulvae. J. Exp. Mar Biol. Ecol. 272, 191-216.

Ouellette, D., Desrosiers, G., Gagne, J.P., Gilbert, F., Poggiale, J.C., Blier, P.U., Stora, G., 2004. Effects of temperature on in vitro sediment reworking processes by a gallery biodiffusor, the polychaete Neanthes virens. Mar. Ecol. Prog. Ser. 266, 185-193.

Peterson, K., Kristensen, E., Bjerregaard, P., 1998. Influence of bioturbating animals on flux of cadmium into estuarine sediment. Mar. Environ. Res. 45 (4), 403-415.

Posey, M.H., Dumbauld, B.R., Armstrong, D.A., 1991. Effects of a burrowing mud shrimp, Upogebia pugettensis (Dana), on abundances of macro-infauna. J. Exp. Mar. Biol. Ecol. 148, 283-294.

Reible, D.D., Popov, V., Valsaraj, K.T., Thibodeaux, L.J., Lin, F., Dikshit, M., Todaro, M.A., Fleeger, J.W., 1996. Contaminant fluxes from sediment due to tubificid oligochaete bioturbation. Water Res. 30 (3), 704-714.

Richardson, M.D., Briggs, K.B., Bentley, S.J., Walter, D.J., Orsi, T.H., 2002. The effects of biological and hydrodynamic processes on physical and acoustic properties of sediments off the Eel River, California. Mar. Geol. 182, 121-139.

Riisgard, H.U., 1991. Suspension feeding in the Polychete Nereis diversicolor. Mar. Ecol. Prog. Ser. 70 (1), 19-37.

Roe, P., 1975. Aspects of life history and of territorial behaviour in young individuals of Platynereis bicanaliculata and Nereis vexillosa (Annelida, Polychaeta). Pac. Sci. 29, 341-348.

Sandnes, J., Forbes, T., Hansen, R., Sandnes, B., 2000. Influence of particle type and faunal activity on mixing of di(2-ethylhexyl) phthalate (DEHP) in natural sediments. Mar. Ecol. Prog. Ser. 197, 151-167.

Scaps, P., Retière, C., Miron, G., Desrosiers, G., 1993. Effet de la ration alimentaire, de la densité intraspécifique et les relations entre individus sur la croissance des juvéniles de l'espèce Nereis diversicolor. Can. J. Zool. 71, 424-430.

Sun, M.Y., Aller, R.C., Lee, C., Wakeham, S.G., 1999. Enhancement degradation of algal lipids by benthic macrofaunal activity: effect of Yoldia limatula. J. Mar. Res. 57, 775-804.

Underwood, A.J., 1997. Experiments in Ecology: Their Logical Design and Interpretation Using Analysis of Variance. Cambridge University Press, Cambridge.

Webb, A.P., Eyre, B.D., 2004. The effect of natural populations of the burrowing and grazing soldier crab (Mictyris longicarpus) on sediment irrigation, benthic metabolism and nitrogen fluxes. J. Exp. Mar. Biol. Ecol. 309, 1-19.

Zoumis, T., Schmidt, A., Grigorova, L., Calmano, W., 2001. Contaminants in sediments: remobilisation and demobilisation. Sci. Total Environ. 266, 195-202. 